Arq. Bras. Med. Vet. Zootec., v.67, n.3, p.664-670, 2015

\title{
Epitheliotropic cutaneous T-cell lymphoma associated with melanoma in a dog: case report
}

\author{
[Linfoma cutâneo epiteliotrópico de células T associado a melanoma em cão: relato de caso] \\ M.I.P. Palumbo ${ }^{1}$, V.J.V. Rossetto ${ }^{1}$, R. Torres Neto ${ }^{1}$, C.V.S. Brandão ${ }^{1}$, R.L. Amorim ${ }^{1}$, \\ V.E. Fabris ${ }^{2}$, L.H.A. Machado ${ }^{1}$ \\ ${ }^{1}$ Universidade Estadual Paulista "Júlio de Mesquita Filho" (FMVZ-Unesp) - Botucatu, \\ ${ }^{2}$ Universidade Estadual Paulista "Júlio de Mesquita Filho"- (FMB-Unesp) - Botucatu.
}

\begin{abstract}
Several types of tumors affect dogs' skin. Simultaneously occurring neoplasms with different histological patterns might be rarely present in the same animal. This paper describes the occurrence of epitheliotropic cutaneous T-cell lymphoma and melanoma in a dog. The animal had nodular lesions in the abdominal region and serpiginous plaques on the dorsal region of the trunk. Cytology evidenced malignant fusiform cells from the abdominal lesions as well as few round cells from the dorsal. The histopathological examination of the abdominal lesions showed dermis with polygonal to spindle-shaped neoplastic cells. The lesion of the dorsal region evidenced neoplastic round cells with generally distinct cell borders and a moderate amount of eosinophilic cytoplasm. Abdominal lesions were positive for Melan A. Dorsal and forelimb lesions were positive for CD3. This study reports the occurrence of epitheliotropic cutaneous Tcell lymphoma and malignant melanoma in a crossbred Boxer dog and discusses the importance of performing immunohistochemical profile to confirm the phenotype of the tumor.
\end{abstract}

Keywords: oncology, immunohistochemistry, malignant skin neoplasms

\section{RESUMO}

Diferentes tipos de tumores podem ocorrer na pele de cães. É rara, porém, a ocorrência simultânea de neoplasias com origens histológicas diferentes no mesmo animal. Este trabalho descreve a ocorrência de linfoma cutâneo epiteliotrópico de células $T$ e melanoma em um cão. $O$ animal apresentava lesões nodulares na região abdominal e placas serpiginosas na região dorsal do tronco e membros. A citologia evidenciou células fusiformes malignas das lesões abdominais, bem como algumas células redondas nas dorsais. $O$ exame histopatológico das lesões abdominais mostrou derme com células neoplásicas poligonais a fusiformes. A lesão da região dorsal evidenciou células redondas neoplásicas com citoplasma eosinofilico. Lesões abdominais foram positivas para Melan A. Lesões dorsais e de membros anteriores foram positivas para CD3. Este estudo relata a ocorrência de linfoma cutâneo de células $T$ epitheliotropic e melanoma maligno em um cachorro Boxer, e discute a importância da realização de perfil imuno-histoquímico para confirmar o fenótipo do tumor. A importância do perfil imunohistoquímico para confirmar o tipo de neoplasia também é discutida.

Palavras-chave: oncologia, imunohistomquímica, neoplasias cutâneas malignas

\section{INTRODUCTION}

Lymphoma is a cancer of hematopoietic origin often observed in dogs; however, its cutaneous presentation is very unusual, occurring in approximately $5 \%$ of the total cases of lymphoma in this species (Moore and Olivry, 1994). Melanomas are relatively common tumors of melanocytes and melanoblasts (Bostock, 1986), representing $6.2 \%$ of cases of skin cancer in dogs (Vail and Withrow, 2007).

Recebido em 14 de abril de 2014

Aceito em 2 de março de 2015

E-mail: palumboma11@yahoo.com.br 
Due to its clinical heterogeneity and microscopic findings, epitheliotropic cutaneous T-cell lymphoma can be further subdivided into three variants, known as mycosis fungoides, Sezary syndrome and pagetoid reticulosis (Moore et al., 2009). Mycosis fungoides is the most common variant of epitheliotropic cutaneous T-cell lymphoma, being distinguished by a prominent epitheliotropic lymphocytic tumor. The pagetoid reticulosis consists of tumor infiltration of $\mathrm{T}$ lymphocytes exclusively in the epidermis and formation of plaque lesions (Moore and Olivry, 1994).

Melanocytic lesions in dogs can be benign or malignant, and can occur anywhere in the body. The malignant melanoma in the dog tends to grow rapidly, can be larger than two centimeters in diameter, and is often ulcerated. As the canine malignant melanoma has a poor prognosis, it is necessary to have an accurate identification method (Withrow and Vail, 2007).

The presence of more than one tumor type in the same animal is not common, occurring in $3 \%$ of all cancer cases in dogs and cats (Rebhun and Thamm, 2010). This study reports the occurrence of epitheliotropic cutaneous T-cell lymphoma and malignant melanoma in a Boxer dog and discusses the importance of performing immunohistochemical profile to confirm the tumor phenotype.

\section{CASE REPORT}

An 8-year-old female Boxer dog was attended due to nodular lesions on the abdominal region that had developed over two years and serpiginous plaques on the dorsal region of the trunk. The dog was in good general condition. Physical examination revealed erythematous nodules, raised serpiginous plaques on the trunk and limbs (Figure 1A), and several ulcerated nodules in the abdominal and inguinal mammary glands (Figure 1B). Blood count and biochemical function tests were normal. Thoracic radiography and abdominal ultrasound ruled out metastasis.

Cytology evidenced malignant fusiforme cells from the abdominal lesions as well as few discrete round cells from the dorsal lesions (Figure 2). An incisional skin biopsy was performed of the abdominal and forelims lesions and tissue specimens fixed in $10 \%$ neutral buffered formalin. The sample was routinely processed, embedded in paraffin wax, sectioned at $4 \mu \mathrm{m}$ and stained with haematoxylin and eosin (H\&E).

Immunohistochemistry was performed with polyclonal rabbit antibodies against CD3 (1:500 dilution, A0452; Dako, Carpenteria, CA, USA), CD117 (1:800 dilition, A4502; Dako, Carpenteria, CA, USA), monoclonal mouse antibodies against CD79a, clone HM57 (1:50 diluiton, K4061; Dako, Carpenteria, CA, USA), Pan cytokeratin, clone AE1AE3 (1:200 diluiton, M3515; Dako, Carpenteria, CA, USA) and Melan A (1:50 dilution, A103; Dako, Carpenteria, CA, USA). Sections were deparaffinized in xylol, hydrated in graded ethanol, and rinsed in distilled water. Antigen retrieval was performed by heat method with citric acid solution ( $\mathrm{pH}$ 6.0) in a pressure chamber (Dako, Carpinteria, USA) for 30 seconds at $125^{\circ} \mathrm{C}$ and then for 25 minutes at $94^{\circ} \mathrm{C}$, and cooled for 15 minutes. Endogenous peroxidase activity was blocked by incubation with $\mathrm{H} 2 \mathrm{O} 23 \%$ in methanol for $10 \mathrm{~min}$. Nonspecific reactions were blocked by incubation with Protein Block, Serum-Free (Dako, Carpintaria, USA) for $10 \mathrm{~min}$ at room temperature. The slides were then incubated with primary antibodies overnight $(18 \mathrm{~h})$ at $4^{\circ} \mathrm{C}$. Immunostain detection was accomplished by use of a polymer peroxidase system (Envision, Dako, Carpinteria, USA) for 45 minutes at room temperature and reactions were visualized with 3-3'-diaminobenzidine (Dako, Carpinteria, CA, USA). Slides were counterstained with Harris' haematoxylin. For negative controls, primary antibodies were replaced by mouse immunoglobulin (CD79a, Pan cytokeratin and Melan A) and rabbit immunoglobulin (CD117) followed by identical staining techniques. For positive controls, positive canine tumors previously tested (mast cell tumor, melanoma and carcinoma) were used. All positive and negative control specimens stained appropriately. 


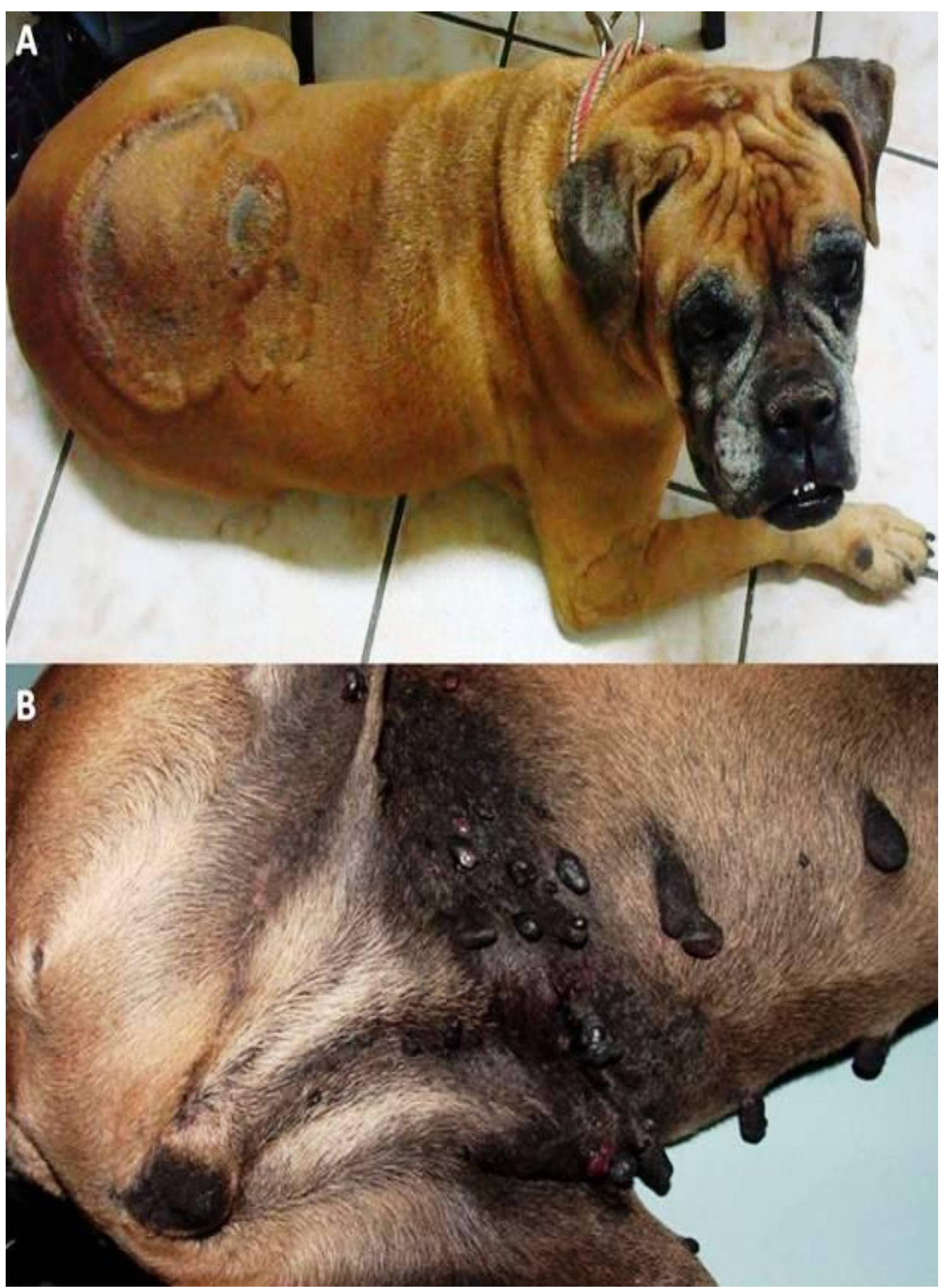

Figure 1. Macroscopic lesions. (A) Raised erythematous nodules with a serpiginous pattern on the trunk. (B) Nodules in the abdominal and inguinal mammary glands; some are ulcerated and with a papillomatous aspect. 


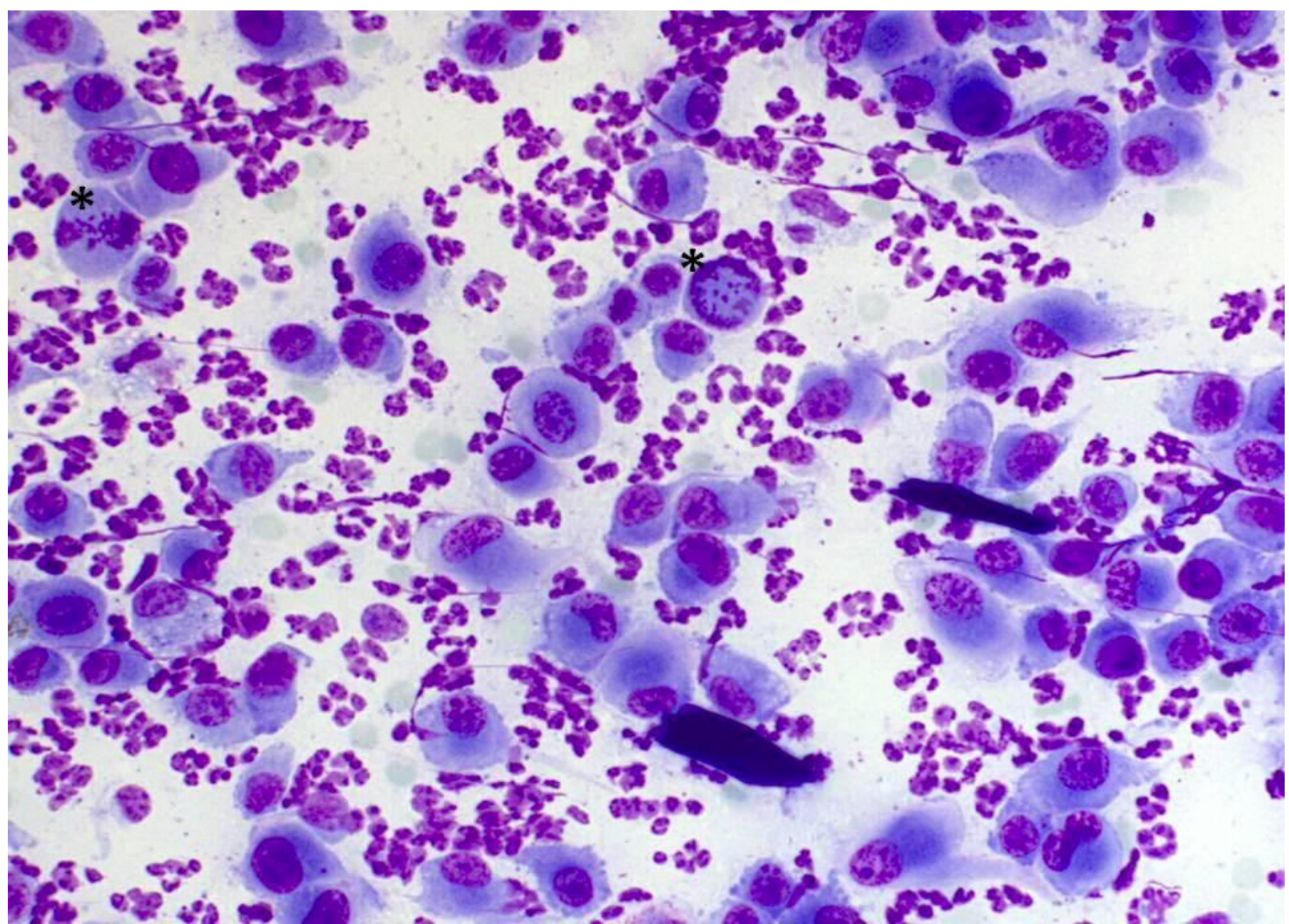

Figure 2. Skin; dog. Abdominal region. Pleomorphic cells, varying in shape from epithelioid to fusiform and occasionally round cells, with basophilic cytoplasm and nuclei with gross chromatin and prominent nucleoli. Two (*) mitotic figures are present into the smear. Citology, Giemsa staining, Magnification: 40x.

The histopathological examination of the abdominal lesions showed dermis with expanded non-encapsulated sheets of polygonal to spindleshaped neoplastic cells. The neoplastic cells had indistinct borders, and a scant to moderate amount of pale basophilic, finely vacuolated cytoplasm. The nuclei were round to ovoid, and had a variably distinct nucleolus and finely stippled chromatin. There was marked nuclear atypia and occasional karyomegaly. There were rare mitoses $(2 / 10 \mathrm{hpf})$. The lesion of the dorsal region evidenced neoplastic round cells with generally distinct cell borders and a moderate amount of eosinophilic cytoplasm. Nuclei were irregularly round and occasionally indented, with finely stippled chromatin, and a single generally indistinct nucleolus. The mitotic rate average was $2 / \mathrm{HPF}$. There was some infiltration of lymphocytes in the epidermis and follicular epithelium. Abdominal lesions were positive for Melan A. Dorsal and forelimbs lesions were positive for CD3 (Table 1) (Figure 3A, B, C e D).

As two different neoplasms were present, we chose chemotherapy for the treatment of the cutaneous lymphoma and an auto vaccine for the melanoma. Surgery was performed in order to obtain material for the elaboration of the auto vaccine followed by cauterization of the nodules. A selective COX-2 inhibitor was administered post-surgery followed by chemotherapy with lomustine (90 mg/m², PO every three weeks). After the first session of chemotherapy hepatic enzymes increased as follows: 1785IU/L alanine aminotransferase (reference values: 21 to 73IU/L); 4,800IU/L alcaline fosfatase (reference values: 20 to $156 \mathrm{IU} / \mathrm{L}$ ) and $116.4 \mathrm{IU} / \mathrm{L}$ gammaglutamyl transferase (reference values: 1.2 to $6.4 \mathrm{UI} / \mathrm{L}$ ). The clinical aspect of the patient worsened after the third chemotherapy with progressive weight loss, apathy and persistent anorexia. After this period the owner chose to interrupt treatment. 


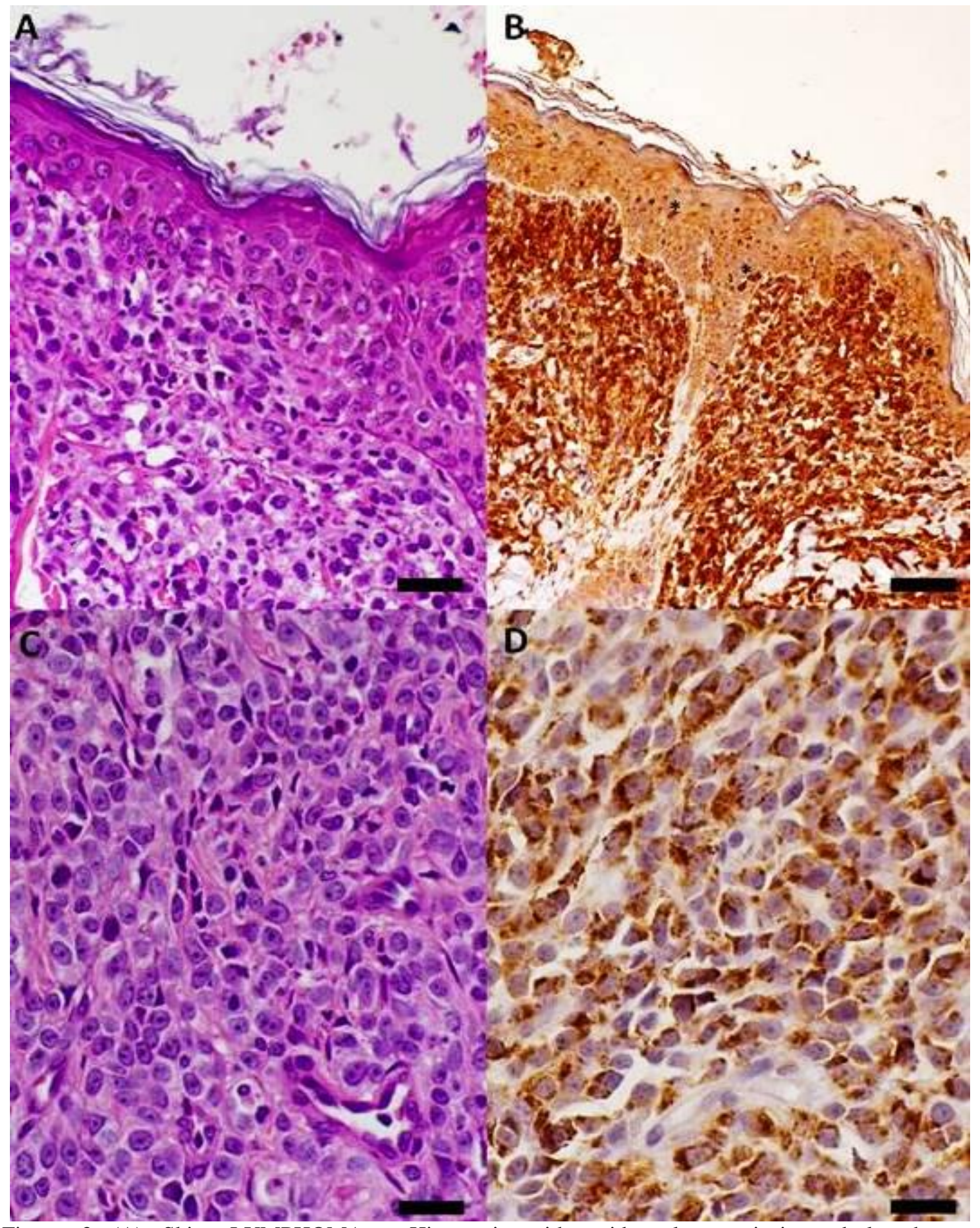

Figure 3 (A) Skin: LYMPHOMA - Hiperpasia with epidermal spongiosis and lymphocyte epidermotropism. Dermis with infiltration of lymphocytes showing nuclear polymorphism, mild eosinophilia and karyorrhexis; (B) Skin; dog. Lymphoma. Note the presence of numerous CD3 antigenpositive lymphocytes in dermis and epidermis $(*)$; (C) Skin: MELANOMA? Atypical epithelioid melanocytes with round nuclei, conspicuous nucleoli, eosinophilic cytoplasm with focal melanin pigment; (D) Dermis; dog. Melanoma. Numerous cells have strong cytoplasmic staining for Melan A. Immunohistochemistry, EnVision, DAB, stain with Harris's hematoxylin counterstain. Magnification: 40x, scale bar: $10 \mu \mathrm{m}$. 
Table 1. Immunohistochemical profile

\begin{tabular}{c|c|c|c|c|c|c}
\hline Sample & CD3e & CD79 $\alpha$ & CD117 & Triptase & Melan-A & cytokeratin \\
\hline $\begin{array}{c}\text { hindlimb nodule } \\
\text { erythematous, raised, } \\
\text { serpiginous pattern) }\end{array}$ & positive & negative & negative & negative & negative & negative \\
\hline $\begin{array}{c}\text { forelimb nodule } \\
\text { (erythematous, raised, } \\
\text { serpiginous pattern) }\end{array}$ & positive & negative & negative & negative & negative & negative \\
\hline $\begin{array}{c}\text { Abdominal nodule } \\
\text { (ulcerated; } \\
\text { papillomatous } \\
\text { appearance) }\end{array}$ & negative & negative & negative & negative & positive & negative \\
\hline
\end{tabular}

Polyclonal CD3, human anti-CD3. DakoCytomation, Denmark; CD79 $\alpha$ : monoclonal, JCB117, anti-human CD79 $\alpha$. DakoCytomation. Denmark; Melan A: monoclonal, A103 clone, anti-human Melan A, DakoCytomation. Denmark; cytokeratin: AE1/AE3, monoclonal, Invitrogen. EUA; Triptase: monoclonal, AA1 clone, DakoCytomation. Denmark; triptase AA1 clone, code M7052, DakoCytomation, 1:2000.

\section{DISCUSSION}

The epitheliotropic cutaneous T-cell lymphoma is an uncommon neoplasm (Moore and Olivry, 1994), while melanocytic tumors are relatively frequent in dogs (Vail and Withrow, 2007). There is no breed or gender predisposition (Scott et al., 2001) but, as in this case, middle-aged and old dogs are often affected (Moore and Olivry, 1994, Vail and Withrow, 2007).

The clinical and histopathological findings from the nodules of the forelimbs in this case are consistent with mycosis fungoides. This nomenclature is due to the gross similarity with lesions caused by some fungi (Sampaio and Rivitii, 2001). The clinical pictures of mycosis fungoides include erythroderma; mucocutaneous ulceration and depigmentation; isolated or multiple nodules and plaques; and oral mucosa ulceration (Scott et al., 2001).

Regarding the microscopic characteristics, tumor proliferation of the mononuclear cells and tropism for the epithelium strongly suggest epitheliotropic cutaneous lymphoma (Cardoso et al., 2006); however, it can be similar to other poorly differentiated round cell neoplasms. Thence, tumor histogenesis was identified using immunohistochemistry. The epitheliotropic cutaneous T-cell lymphoma is normally positive for CD3 and negative for CD79a (Cardoso et al., 2006; Daleck et al., 2009). This immunomarking pattern indicates that the neoplasm derives from a $\mathrm{T}$ cell lineage, but does not differentiate between helper (CD4+) and cytotoxic (CD8+) populations. The most common subpopulation in dogs consists of CD8+ lymphocytes; while in humans, CD4+ populations are more often associated with the presence of this neoplasm (Moore et al., 2009).

Melan A is one of the most commonly used monoclonal antibodies in the diagnosis of melanoma in human and veterinary medicine (Giudice et al., 2010); nevertheless, it is not specific for malignant tumors. These tumors can be diagnosed by fine needle cytology. However, the histological analysis is important to determine the malignancy potential (Vail and Withrow, 2007). In this case, the use of Melan A for the abdominal samples confirmed melanoma, and the velocity of appearance and growing of the nodules suggested a high degree of malignancy. The histopathological examination did not help the diagnosis because it suggested a poorly differentiated mast cell tumor.

There are few reports on the association between melanoma and lymphoma in humans (Verwer et al., 2010) and in dogs (Rebhun and Thamm, 2010). Humans with melanoma have 24 to $32 \%$ chance of developing another malignant neoplasm, including non-Hodgkin's lymphoma (Bradfort et al., 2010).

The relative risk of developing non-Hodgkin's lymphoma subsequent to melanoma varies from 1.42 to 16.1 times (Riou et al., 1995). It is thought that exposure to carcinogenic factors common for both neoplasms as well as genetic susceptibility are involved in the etiology of the tumor (Bradfort et al., 2010). 
According Rebhun and Thamm (2010), animals with malignant melanoma, mast cell tumor and thyroid carcinoma are more susceptible to developing more than one type of neoplasm simultaneously. Moreover, the effects of previous treatment such as radiotherapy and chemotherapy might also predispose to a secondary neoplasm. (Rebhun and Thamm, 2010). Riou et al. (1995), state that previous treatment would be responsible for immunosuppression, especially of T-cells, preventing the recognition of a new primary neoplasia. Nevertheless, our patient had not been treated with chemotherapy, radiotherapy, or any immunosuppressive drug previous to the emergence of the lesions.

The etiopathogeny and the relation between the neoplasms involved in this case could not be confirmed. It was also not possible to identify which was the initial neoplasm. Although exposure to carcinogenic agents and genetic abnormalities, mainly in genes associated with the immunological status of the individual, are the most plausible causes of association of these neoplasms, further prospective studies in veterinary medicine are necessary in order to elucidate the possible predisposing factors.

This report highlights the importance of immunohistochemistry in order to determine the histogenesis of the tumors, allowing a definitive diagnosis, a reliable prognosis, and supporting the practitioner in the choice of the treatment that is appropriate for each patient. The practitioners should be aware of the presence of different types of neoplasms in the same animal.

\section{REFERENCES}

BOSTOCK, D.E. Neoplasms of the skin and subcutaneous tissues in dogs and cats. Br. Vet. J., v.142, p.1-19, 1986.

BRADFORT, P.T.; FREEDMAN, D.M.; GOLDSTEIN, A.M. et al. Increased risk of second primary cancers after a diagnosis of melanoma. Arch. Dermatol., v.146, p.265-271, 2010.
CARDOSO, M.J.L.; NETO, R.T.; AMORIM, R.L. et al. Micose fungoide em um cão. Vet. Zootec., v.13, p.137-143, 2006.

DALECK, C.R.; NARDI, A.B.; RODASKI, S. Oncologia em Cães e Gatos. São Paulo, ROCCA, 2009, 612 p.

GIUDICE, C.; CECILIANI, F.; RONDENA, M. et al. Immunohistochemical investigation of PNL2 reactivity of canine melanocytic neoplasms and comparison with Melan A. J. Vet. Diagn. Invest., v.22, p.389-394, 2010.

MOORE, P.F.; OLIVRY, T. Cutaneous lymphomas in companion animals. Clin. Dermatol., v.12, p.499-505, 1994.

MOORE, P.F.; AFFOLTER, V.K.; GRAHAM, P.S. et al. Canine epitheliotropic cutaneous Tcell lymphoma: an investigation of $\mathrm{T}$-cell receptor immunophenotype, lesion topography and molecular clonality. Vet. Dermatol., v.20, p.569-576, 2009.

REBHUN, R.B.; THAMM, D.H. Multiple distinct malignancies in dogs: 53 cases. J. Am. Anim. Hosp. Assoc., v.46, p.20-30, 2010.

RIOU, J.P.; ARIYAN, S.; BRANDOW, K.R. et al. The association between melanoma, lymphoma, and other primary neoplasms. Arch. Surg., v.130, p.1056-1061, 1995.

SAMPAIO, S.A.P.; RIVITII, E.A. Leucemias, linfomas e pseudolinfomas. In: SAMPAIO, S.A.P.; RIVITII, E.A. (Eds.). Dermatologia. São Paulo: Artes Médicas, 2001. p.1156, 2001.

SCOTT, D.W.; MILLER, W.H.; GRIFFIN, C.E. Neoplastic and non-neoplastic tumors. In: SCOTT, D.W. (Ed.). Muller \& Kirk's small animal dermatology. 6.ed. Philadelphia: Sauders, 2001. p.1333-1338.

VERNER, N.; MURALI, R.; WINSTANLEY, J. et al. Lymphoma occurring in patients with cutaneous melanoma. J. Clin. Pathol., v.63, p.777-781, 2010.

WITHROW, S.J.; VAIL, D.M. Tumors of the skin and subcutaneous tissues. In: WITHROW, S.J.; VAIL, D.M. (Ed. ${ }^{\text {th }}$ ) Saunders Elsevier, St Louis, pp.375 -401, 2007. 